other hand, this Council partly emanates from and may have most important relations with the Privy Council. In the constitution of the Privy Council you must bear in mind that six of our number-a fourth of the whole-are nominated by her Majesty with the advise of her Privy Council.

Also by Clauses 20 and 21 of the Acts we are directed under certain circumstances to make representations to Her Majesty's Most Honourable Privy Council, and not to the Home Secretary. The Privy Council is called upon, if it shall think fit, to enforce any representations or regulations emanating from this Council.

Again, by Clause 23, it is the Privy Council which is directed to prohibit attempts on our part to impose restrictions upon the practice of medicine and surgery, and the Vice-President of the Committee of the Privy Council on Education is especially directed to take part in any orders connected with carrying out the regulations of this Medical Council.

It appears then from all that I have just advanced, that, as we are a Council of Medical Education, and have much to connect us with Her Majesty's Privy Council, it would henceforth be more expedient and proper that we should seek the assistance of the Lord President of the Privy Council to introduce any Bill into the House of Lords, rather than again fruitlessly seek the assistance of the overworked Secretary of State for the Home Department in the House of Commons.

I must next say a few words upon an Act of Parliament recently passed termed "An Act to amend the law relating to Medical Practitioners in the Colonies." Prior to the introduction of this Bill into the House of Lords by the Duke of Buckingham there were forwarded to me by direction of $\mathrm{Mr}$. Hardy various documents relating to it, and I was requested to peruse them, and return them with my opinion upon them. Having read them, I fortunately had the opportunity of conferring with the Executive Committee before I wrote my reply to the Home Secretary's communication. I made various sug gestions in reference to the proposed legislation in my letter, which I now place on the table, because it has not before been brought under your notice.

When the Duke of Buckingham proceeded with his Bill I found that all $\mathrm{my}$ suggestions contained in the letter to the Home Office had been entirely ignored. I therefore immediately applied for an interview with the Colonial Secretary, and this being granted, Dr. Sharpey and Mr. Hawkins kindly accompanied me to the Colonial Office. When offering our objections to the Medical Practitioners (Colonial) Bill, I adverted to my letter, as President of this Council, on the subject, when his Grace informed us that he had never seen nor heard of any such letter from the President of the Medical Council; in truth, it had never been transmitted to his Grace from the Home Office. Fortunately, I was provided with a copy of the letter, which I then read to the Duke, and left it with him. The result was the objectionable parts of the original Bill were amended, and the measure has now passed in a form to which little objection can be made.

There is one other topic to which I may briefly allude before I sit down, and that is the prospect there is of your being invited to look into your own constitution, and decide whether you think that constitution would be improved by an increase of your number and by the introduction of members who are to represent interests, which it is alleged by some persons are not duly represented in the Council. It could hardly be expected, in this era of radical reforms and organic changes in the Legislature, that this Council, which has hitherto been regarded as fairly representing the profession for those pur. poses for which it was constituted, should remain undisturbed, and that attempts would not be made to alter its constitution and character. I am sure I am expressing the sentiments of all when I say, that whenever this question is properly brought before us, we shall be prepared to give a patient, careful, candid, and temperate consideration to the arguments and reasons by which such a proposal is supported.

Lastly, it is a duty which $I$ owe to the members of the Council to remind them of a circumstance to which I have already alluded, that my term of office as President will probably have expired before the next annual session of the Council. Now it is all essential to the future harmony and credit and good working of the Council that this question of the election of my successor to the honourable and distin. guished office of President should not take you by surprise. You will during the present session have frequent opportunities of personal intercourse, and I trust you will make this one of the topics of private, friendly discourse, -it can hardly be discussed in public. Then as to the precise date when I $\mathbf{s}$ hould vacate my office? Whatever course may most contri- bute to the convenience of the Council, and be most conducive to uphold the dignity and honour of the office, will be the most acceptable to my feelings.

\section{CASES IN MEDICAL JURISPRUDENCE.*}

\section{BY W. BURKE RYAN, M.D. LOND., F.R.C.S.}

CASE 1. Atelectasis Pulmonum in a child five weeks old.This case is probably unique in the annals of medical jurisprudence, and will afford a lesson in medical ethics which may deserve attention.

On Jan. 4th, 1859, a child, aged five weeks, died in Ledburyroad. A medical gentleman, visiting another party in the house, was told of the circumstance, and shown a mixture which had been obtained the night before from a surgeon who had not seen the child, and of which a teaspoonful had been given. This gentleman very incautiously examined the bottle, and still more injudiciously expressed an opinion that there was laudanum enough in it to have killed the child.

After this of course an inquest was indispensable, and Dr. Chas. Clarke, now of Adelaide, was requested by Mr. Wakley to make a post-mortem examination. He wished my assist. ance, and I now give a short description of the appearances presented, as well as of a microscopical examination kindly made by the late Mr. Quekett, accompanied by two drawings on wood by Mr. Searson, under Mr. Quekett's supervision. The result will show how annoyingly the matter might have turned in ordinary cases against the surgeon prescribing, while the facts adduced can only make it a matter of the utmost surprise how the child could have lived to the time it did. I regret that the space I conld expect in the pages of THE LANCET prevents my entering fully into the literature of the subject.

The following is the composition of the mixture, of which scarcely a teaspoonful was given eight hours before death : Syrup of squills, two drachms; compound tincture of camphor, sixteen minims; water, one ounce. It will be seen that two drops of the compound tincture of camphor could hardly be said, even under such circumstances, to have a deleterious influence. Besides, the child had no appearance of having during life suffered from an opiate.

Emily $P_{-}$, aged five weeks, laboured under cough on the evening of Jan. 3rd, 1859, and died on the morning of the 4th. The mother, after attending to the child, fell into a short sleep, and when she awoke the child was dead. The postmortem examination took place on the 11th. The child seemed in good condition of body, rather plump, with a rosy hue on the parts exposed to atmospheric action. The brain was evidently much congested, black dots appearing on slicing it transversely. The blood was dark and' clotted in the sinuses and veins. No appreciable effusion into the ventricles. The thymus gland was large, and gorged with a white fluid of a chylous character, about half a drachm of it occupying the central cavities. On opening the thorax the lungs presented a solid appearance, firmly contracted towards the back part of the chest, inelastic, and leaving much of the pericardium exposed; no crepitation in any part, and in cutting into them they showed all the appearance of lung in a fœtal state-the usual sanguineous serum being absent; they weighed 18 drachms, or 1080 grains. The pericardium contained two or three drachms of serum, and the heart itself was plump, hard, and enlarged, as if bursting with its contents. The right chambers were filled with perfectly black, clotted blood, which was equally black, but in small quantity, in the left. Each pleural cavity contained about an ounce of serum. The foramen ovale and ductus arteriosus were pervious. The stomach was nearly empty, containing about two drachms of dark grumous fluid. The liver was large and fully congested, as were also the kidneys. On cutting into the abdominal walls a deposit of fat was observed, and the intestines appeared healthy.

With the heart attached the lungs sank rapidly in water; the heart being detached they also sank rapidly in their en. tirety. They were divided into several pieces, and all sank quickly, so as to cause Mr. Wakley to say to the jury that he had never seen anything approaching it before, and to express his surprise how the child could have lived; adding that it could only have required the slightest impediment to respiration in order to cause death. Not the smallest piece floated. On inflating part of the lung it partially floated, but most of

\footnotetext{
* Read in abstract before the Royal Medical and Chirurgical Society.
} 
the air soon escaped again. Indeed, inflation was quite im. perfect, the air entering with great difficulty, as if owing to an inexpansible condition of lung.

I left several pieces of the lung with Mr. Quekett, together with a nnte saying, "I now send you the pared-off edges of the uninflated lung. You will find two of the pieces, weighing only one-half and three-fourths of a grain respectively, which sink as rapidly as the rest. An examination of these is perhaps all that is necessary in order to render the subject perfect." Some inflated portions were also sent. Mr. Quekett replied as follows :-

"Royal College of Surgeons, Mray 7th, 1859.

"Dear Sir,-I have made many observations upon the lung of the young child which you put into my hands for that purpose. I find that by far the greater part of the specimens are so much solidified that they not only sink in water, but, on examination with a pocket lens, exhibit little if any trace of ces- $_{2}$. lular structure. A few pieces (and these $I$ have since learnt had been attempter to be inflated) sink much less readily in water; in these a slight trace of air-cells may be seen with a pocket lens, but on making thin slices and examining them with a power of 250 diameters, all the more solid parts appear to be made up of small cells or granules, which, for want of a better name, may be called exudation-cells. These cells adhere very firmly together, so that a section, however thin, when placed in water between glasses for microscopic examination, was so coherent that the operation of tearing with needles would hardly allow of a proper isolation of the individual cells, and such a section would present the characters indicated by Fig. 1. In some parts there were slight indications of fibrous tissue, which was not disposed in the form of circles, like that employed in the construction of the framework of the air-cells. Thnse parts of the lung which were above stated to exhibit under a low power the characters of fotal lungs in general, when treated in the same way as the more solid parts, certainly exhibited the fibrous structure of the air-cells very distinctly in some points; but although the air-cells were marked out, as shown in Fig. 2, they were in most instances filled up by the small granules or cells, which rendered them almost as solid as the denser portions shown in Hig. 1."

Fig. 2.

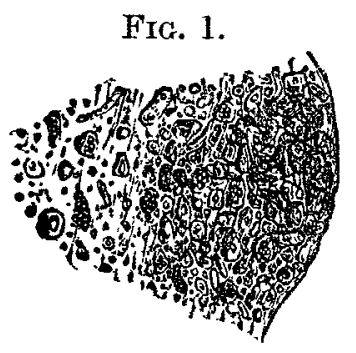

Dense portion of rotal lumg. 120 diam

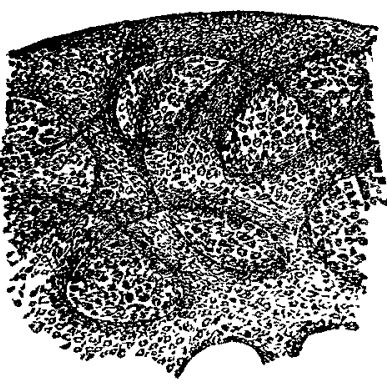

Air-colls marked out. 90 diam.
The fact that the lungs of children who had breathed, and lived even for a considerable time, will sink in water, was noticed by Morgagni, De Haen, Kieffer, Wrisberg, Hoffman, and others; but Dr. Edward Jürg, of Liepzig, was the first fully to investigate and describe the state of things which led to this, under the name of atelectasis, or incomplete expansion or permanence of the fretal condition of the lungs. It may be either an absolute disease, or may arise from great weak. ness on the part of the child, or mechanical impediment to inspiration preventing full expansion in an otherwise normal lung. Dr. Jörg believed that this unexpanded state of lung might occur in mature or immature children, and that the process of parturition much influenced such a result : for instance, where the head was subjected to great pressure, or where, on the other hand, a very rapid delivery took place, as well as in cases where children lose much blood by the umbilical cord, or are born with powers so feeble that they cannot live without placental circulation. I append a case of this latter description. If the first inspirations, owing to certain conditions of the child, be feeble, part of the lungs may become inflated, while other parts remain wholly unreached by atmospheric air, and will thus remain in an unexpanded state, and may subsequently become consolidated or deteriorated, so that many, or, as in the present case, nearly all traces of vesicular structure may disappear; or it may so happen that vesicular structure may have been undeveloped from the first, commencing with positive disease. *

The subject is involved in much ohscurity, and we are wholly * Do Palmón Vitio Or rauleo, Lipsiz, 1832. Die Fötuslunge, Grimma, 1835. at a loss to account for the fact of children living even for a considerable time, and yet after death leaving no traces of respiration, the lungs, in fact, appearing in their foetal condition. Bernt gives three cases, one of which had arrived at the full period of utero-gestation, and lived a day. The lungs sank when tried in their entirety. and on being cut, a few fragments only, of a scarlet colour, floated. In another case the child was a seven months one, lived two hours, and its lungs sank in water.

In Henke is given a case by Remer, where a child lived four days, so that the funis had time to separate naturally. The lungs, whole and in fragments, sank in water. Heister* gives a case where a very feeble infant lived nine hours, whose lungs sank; and Orfilat found every portion of the lungs sink in water in a child that had lived eleven hours; and in three other cases, two being mature, in which the children lived four, six, and ten hours respectively, the lungs sank when divided. Billard, $\neq$ from meeting some cases of this kind, imagined that it was possible for children to survive their births cven days without breathing. Schenk mentions the case of an infant who cried several times during the four days it lived, and yet its lungs sank in water.S The substance of the lungs was healthy; there was no crepitation. The lungs being separated, and cut each into fifteen pieces, all sank rapidly to the bottom, no bubbles escaping on compression below the surface of the water. The other case was that of a mature child that lived sjx hours, and whose lungs sank in water. In Dr. Albert's case the child lived thirty-six hours, being occasionally convulsed. On inspection there was no appearance of disease. The whole lung appeared in a fœtal condition, and immediately sank in water.

The case here described is the only one I find on record of perfect atelectasis in a child so old. The sinking in water was not, presumably, the result of any disease other than that of non-development or deterioration of the vesicular structure. Appearances resulting from diseases, such as congestion, hepatisation, pneumonia, scirrhus, œdema or tubercle, would have been very different and distinguishable by care, while the puzzling nature of the present case is still more fully borne out, as well as its interest enhanced, by the careful microscopical examination of Mr. Quekett. Had the state of the lungs been the result of any known form of disease the cellstructure could scarcely have been altered to the form described. Some fragments of lung must have floated in water, and the weight should, at the end of five weeks, have exceeded 1080 grains $\left(2 \frac{\mathrm{oz}}{\mathrm{o}}\right)$

CASE 2, wherein a foetus arrived at the end of the fifth or beginning of the sixth month of uterine life, and weighing not quite $1 \frac{3}{4}$ lbs., after twenty-eight minutes' occasional respiration, a small portion of lung floated in water. - I attended Mrs. $\mathrm{H} \longrightarrow$ in a case of typhoid fever. She was in her fourth pregnancy. My attendance commenced on May 6th, 1859, and on June 4th, at which time she considered she was about tive months pregnant, she was delivered of a very diminutive fœtus. The child was alive, moved, and breathed very feebiy occasionally, but emitted no sound, and the chief evidence of life was given by the heart's action, and by the placental circulation, which was strongly kept up. I folded the infant in flannel and watched the resnlt $w$ ith much interest. The placental circulation was carried on for about twenty-eight minutes, gradually getting weaker, and the moment it ceased life seemed extinct.

The weight was $1 \frac{3}{4}$ lbs. less 1 drachm. The heart, lungs, and thymus gland weighed $1 \mathrm{oz} .75$ grs. avoirdupois, and sank in water, as they did when the thymus, which weighed 32 grs., was separated.ll Both lungs sank rapidly when separated. The left lung, cut into fragments, sank. The upper and middle lobes of the right lung were cut into twenty pieces, and all sank; the lower lobe was cut into tifteen pieces, and all sank but two, weighing $3 \frac{1}{4}$ grs. and $3 \frac{1}{2}$ grs. The heart weighed 102 grs., thus leaving the weight of the lungs 420 grs. Foramen ovale quite open, and ductus Botalli pervious. Right auricle and ventricle full of black blcod. Left auricle contained about two or three grains' weight of black blood, and the left ventricle was quite empty.

\footnotetext{
* Morgagni's Works, rol. i.

+ véd. Lég., i., 375

+ Maladies des Enfans, Viabilité.

Journal der Piatischen Heilknnde, Band xxvil, Sect. 3.
}

Mr. Divies mentions a case ( $14 e d$. Guz., rol. xl., p. 1022) of a child 19 [b. in weight that lived ten minutes, but no post-rnortem was made.

Psoriasis has, by an Italian writer, been put in juxta-position with scurvy. The latter is caused by an exclusively animal diet; the former by excess of vegetable food. Advise against psoriasis a modified Banting system (leave out wine and spurits), aud you'll succeed. 